\title{
DEVELOPMENT ECONOMICS AND THE WORLD BANK'S IDENTITY CRISIS
}

\author{
Luiz Carlos Bresser-Pereira \\ Review of International Political Economy, \\ 2 (2) Spring 1995: 211-47
}

\begin{abstract}
In this article, the author, the Brazilian Finance Minister in the late 1980 s, uses his insights and experience to examine critically the identity crisis of the World Bank. Trapped by the neo-liberal turn in the 1980s, and unable to return to the Keynesian lending principles of earlier decades, the Bank is claimed to be facing an unsettled future in terms of its operational philosophy.
\end{abstract}

The World Bank is an institution that grew and affirmed itself out of confronting crises or challenges. Since the 1980s it has faced three of them. First, the growth strategy it originally adopted has blurred since the late 1970s, when development economics fell into a deep crisis and the role of the state in the economy was challenged. Second, the very idea of a development bank is at bay, as the Bank tends to lose the role of a net provider of funds to developing countries. Third, the Bank performed poorly when the foreign debt crisis broke out in the early 1980s. The three problems could be summed up as an identity crisis. After all, what is the World Bank? Does it remain a development bank, as was the design of its founders, or is it changing into a kind of commercial bank that rolls over debts and a service institution that advises developing countries, taking advantage from the fact that it assembles the largest group of competent economists specialized in economic and social development in the world? Is it mainly an institution oriented to economic development or a political and ideological institution obeying the policies of its main shareholders? In a world where development remains a major long-term challenge, is it a valid role for the Bank to try to solve short-term stabilization and balance of payments problems, as it was compelled by the debt crisis in this way directly competing with the International Monetary Fund - or should it redefine and pursue a new growth strategy?

Fifty years after its creation, the strategy the Bank should follow to accomplish its development mission is not as clear as it had been. The mission 
itself remains clear: to promote economic development, to reduce poverty. But the very idea of a development bank is at bay. First, if the Bank accepts the conservative assumption on economic development that it is possible to rely exclusively on the private sector to achieve prosperity, why do we need a development bank? And where do development economics, which inspired the Bank's initial strategies, or the new endogenous theories of growth, that represent a revival and a sophistication of these ideas, stand? Second, does the Bank possess the financial means to remain a development bank? When it was created, the assumption was that the Bank would finance countries in a similar way to investment banks financing industrial projects. For some time the Bank would have a negative cash flow with a given country, but, once this nation turned developed, the flow of funds would be reversed. Presently, for most countries this flow has indeed been reversed, it has become negative, although a satisfactory stage of growth has not been achieved. If this is so, if it is not realistic to expect new substantial capital increases for the Bank nor a higher external indebtedness, so that it has no other alternative but to stop being a net provider of funds to developing countries, may the Bank still be regarded as a development bank? Third, given the fact that today most developing countries are highly indebted, needing debt reduction rather than new flow of funds, what role can the Bank play in relation to them? Is it sufficient just bailing out the commercial banks, substituting public financing for private, and asserting that the debt reduction involved in the Brady Plan is enough, or is there a more sensible alternative?

These questions are not new in the Bank or in Washington. Since the late 1970s the Bank has been trying, in several ways, to respond to them. The introduction of the structural adjustment loans, coupled with structural reforms and conditionality, and the self-definition as a service institution are the two major responses to the challenges the Bank faces. And, similarly to the position it adopted in relation to the debt crisis, they were responses to the political pressures coming from its major stockholders and to the conservative neoliberal wave that dominated Washington in the 1980s. Were these responses appropriate?

Today there are signs that the conservative wave is lessening and that a renewed development economics, now more oriented to assist the market rather than replace it, is resurging. On the other hand, the economic performance of Japan and the Asian NICs shows that state intervention may not hinder foreign and internal competition, when government action is directed to stimulate competitiveness rather than protect inefficiency. To what extent is the Bank now acknowledging these new realities? 
These are questions I will try to answer in this article. I know these are complex questions that only admit tentative and partial responses. Some, as the overlapping between the Bank and the Fund, I will expressly avoid. It is a false issue that has already received too much attention. Overlapping is inevitable, and, up to a certain point, desirable as all forms of competition are. Others, I will address more carefully, particularly those concerned with the definition of the Bank's identity. I will give a particular emphasis to the political economy of development. The World Bank's identity crisis arises as much from the successes of development economics as its failures. Unfortunately subsequent analyses have not interpreted the problem correctly, and much of this has been willful on the part of some countries with considerable influence on the Bank policies. Development economics, as it was originally elaborated in the 1940s and 1950s, followed a political economy approach. This approach was also present in the original ideas that oriented the World Bank. As this approach was lost, the Bank was faced with an intellectual crisis that it was not able to overcome.

\section{The Original Objectives}

When the World Bank was founded, its mission was quite clear: to help the reconstruction of Europe and to promote economic growth in the rest of the world. The basic strategy was industrialization. The means to achieve it were foreign finance for infrastructure investments and the protection of infant industry. The theoretical tool behind it was development economics, a new branch of economics.

The Bank's primary objective - to help the reconstruction of Europe - was successfully achieved. Already by the 1960s the leading countries in West Europe were not depending on the Bank's loans. The basic economic and educational infrastructure was already there. The internal saving capacity was soon recovered. The Marshall Plan plus additional loans provided by the Bank were effective in helping the European countries to reestablish the prewar living standards and to permit the region to resume growth.

The second objective - to help developing countries to start industrialization and growth - was also achieved in most countries in Latin America and Asia. Only in Africa are results still unsatisfactory in this area. But one thing is to start growing and changing from a precapitalist or a mercantilist economy to an industrial capitalist one, and quite another to achieve an 
acceptable level of development, to stop being underdeveloped. ${ }^{1}$ This second objective was clearly not achieved. The difference between the First and the Third World, between North and South, remained essentially the same forty or fifty years after the Bank was founded.

This fact could have been taken naturally, but it was not. The hopes in the 1950s were high. Disappointment, in the 1980s, was correspondingly high. Celso Furtado (1987), one of the pioneers in economic development, manifested this disappointment dramatically. After summarizing his own contributions to development economics, he asserts that to overcome underdevelopment a more encompassing rationality is necessary than the one offered by markets. It is not the case of increasing the entrepreneurial role of the state, but of preventing the structural resistance to the reduction of social inequalities and orienting the investment process to meet the basic needs of the population. And he concludes: 'on this area... the Brazilian experience was disappointing'. Albert Hirschman (1979) also manifests his disenchantment, but in a rather critical way. The optimism that prevailed after World War II among economists and policymakers on the prospects of growth evaporated. The division of the world into rich and poor countries remained unchanged, in the poor countries the fruits of growth have been unevenly distributed, and many countries have been victims of new authoritarian regimes.

In the 1980 s, when the rise of new democracies opened the way for a new optimism, the economic stagnation in Latin America, originating in the debt crisis and the consequent fiscal crisis of the state, cut short this optimism. On the other hand, the remarkable economic progress in East and Southeast Asia, where, after a short import substitution period, export oriented strategies have prevailed since the mid-1960s, precipitated the crisis of development economics - a crisis that Hirschman remarks on as early as 1979 , when he wrote the essay 'the rise and decline of development economics'. In many ways development economics could have presented the successful story of the Asian tigers as a confirmation of the big push idea. Yet, it was unable to do that, given its initial commitment to the import substitution strategy - a development strategy whose existence the military governments in Latin America artificially extended in the 1970s, using for that foreign financing. The neoliberal economists, helped by the breakdown of the Keynesian consensus and the rise of a conservative wave in the First World, were the ones who used this success story to reaffirm the neoliberal credo and accentuate the crisis of development economics. The fact that the economic development of the Asian tigers was based on state intervention even more than in Latin America was ignored. The very idea of a development strategy based on the combination of state action and private entrepreneurship, that was dominant when the Bank was founded, was replaced with an aggressive anti-state ideology 
in the First World, that, in Washington, eventually culminated in the neo-liberal or quasi neo-liberal 'Washington consensus'.

\section{Development Economics and the Bank}

The crisis of development economics and the emergence in the 1980s of a kind of neo-liberal consensus in Washington embodied a crisis- specifically an intellectual crisis - for the World Bank, since it was founded and institutionalized on the basis of development economics. The basic tenets of development economics were also the principles that originally oriented the institution and the action of the Bank.

Development economics emerged in the 1940s as a basic critique to neoclassical economics. Keynes, in the 1930s, developed the macroeconomic critique, i.e. the short-term or business cycle critique, of neoclassical thinking. Development economists, two decades later, made a complementary critique on a long-term viewpoint. The basic objectives of the new theory were: (1) to legitimate industrialization, given the historical, obvious argument that all developed countries were industrial countries (Kuznetz 1966); (2) to increase savings and investment capacity of underdeveloped countries from around 10 to 20 per cent of GDP; ${ }^{3}$ (3) to promote the take off into sustained growth (Rostow 1960).

Behind theses objectives development economics offered a basic diagnosis of the causes or the characteristics of underdevelopment: economic dualism (Boëke 1953), unlimited supply of labour (Lewis 1954), low savings, lack of motivation for entrepreneurship (McClelland 1961; Hagen 1962); deterioration of the terms of trade for primary-good producers (Prebisch 1950; Singer 1950), mercantilist style of colonization as opposed to the settlement style that was dominant in some regions such as New England (Prado 1945; Furtado 1961). The last two causes could be related to the imperialist type of explanations, dominant among Marxists, but the emphasis of development economics, as Hirschman (1981) pointed out, was not on this aspect but in the 'mutual-benefit claim'. Development economists did not deny colonialism and imperialism, but they were more interested in exploring the opportunities of mutual gains among developed and underdeveloped countries. Development economics is a nonorthodox theory, but it is not a radical one.

The mutual-benefit claim appears clearly in one of the two basic strategies development economics formulated to achieve industrialization: the big-push or the balanced growth strategy (Rosenstein-Rodan 1943, 1961; Nurkse 1953). The big-push idea - a dramatic and cross-fertilizing increase in investment - was one 
of the theoretical bases for the World Bank's strategy of giving priority to financing infrastructure. The second basic strategy - protection to infant industry, import substitution - also received support from the Bank. Yet, already in the 1960s the Bank changed its views on this subject, as industries ceased to be infant and import substitution stopped being an industrialization strategy and turned into mere protectionism.

Development economics is based on the existence of externalities. Industrialization cannot be the result of incremental or gradual efforts. A bigpush, an initial 'minimum critical effort' (Leibenstein 1957), the definition of 'growth poles' (Perroux 1955) is necessary or advisable. Economic growth is a historical process, where discontinuities and jumps are part of the game. The transition from an agricultural - traditional or mercantilist society - to an industrial one is the basic leap with which development historically begins. In order to industrialize a country, industrial projects must be individually profitable. But, if the firm considering the project does not count on the benefits from the external economies produced by other already existing firms, the project will not be economically attractive. The investment will not take place. Thus, 'the complementarity of different industries provides the most important set of arguments in favor of a large-scale planned industrialization' (Rosenstein-Rodan 1943: 249). This was the theory of 'balanced growth': investment would have to take place simultaneously in various industries, according to a planned design, so that the benefits from externalities were fully exploited.

Hirschman (1957), with the concept of forward and backward linkages, borrowed the concept of externalities, but discarded balanced for 'unbalanced growth': economic development cannot be planned. What policymakers can do is to promote strategic investments that create opportunities for entrepreneurship. For Hirschman it was already clear at that time that government economic action should not be equated with economic planning replacing the market. It should rather correct and complement the market and the entrepreneurial initiative.

In order to finance the initial steps of industrialization three basic methods were advocated: (1) income concentration favoring the capitalist (industrialist) class; ${ }^{4}(2)$ forced savings, that should be extracted from the primary-goods export sector through taxation or from society in general through inflation, and transferred to the industrialists or to the state-owned enterprises investing in infrastructure; ${ }^{5}$ and (3) foreign financing, where the role of the Bank would be crucial, particularly to finance government projects.

The last phrase suggests why I have been revising in detail, old ideas on development economics. These ideas, plus the shortage of capital and the conviction that there was considerable room for improving the management of 
available resources, were at the core of the Bank strategy. Development economics gave an additional but essential rationale for the existence of the Bank. It was created by national governments, having as specific purpose and strategy to exclusively finance the state. Why? Because it was very clear in the first decades of the Bank's operations that capitalist development remained the job of private entrepreneurs, but the state was supposed to perform a strategic role in this process. Businessmen could be financed by commercial banks, but the huge investments in infrastructure should be financed by a special development agency: the Bank. Besides maintaining sound macroeconomic conditions, the governments in the developing countries were supposed to directly realize the infrastructure investments with large forward linkages and to stimulate private investments with backward linkages. The investment projects would be evaluated and financed by the Bank. The objective was to create capitalist economies, not centrally planned ones, but some degree of indicative planning was assumed to be necessary. ${ }^{6}$ Cost benefit analysis, shadow prices, project evaluation methods were at the centre of the Bank's activity. Not only industrial projects but also agricultural ones should follow the general planning procedure. $^{7}$

It is true that, originally, when it was created at Bretton Woods in 1944, it was not clear to the delegates that the role of the Bank would be to essentially finance national governments, nor that the state was supposed to have a strategic role in development. The basic objective of the Bank in relation to the less developed countries (LCDs) was

to promote private foreign investment by means of guarantees of participations in loans and other investments made by private investors; and when private capital is not available on reasonable terms, to supplement private investment by providing suitable conditions, finance for productive purposes out of its own capital, funds raised by it and other resources. ${ }^{8}$

Thus, only in a subsidiary condition should or could the Bank finance government projects.

During the first years of operation of the Bank, Mason and Asher state that 'the Bank management was opposed to financing government owned industries'. In its first five years the Bank only financed a few state-owned enterprises, primarily in France and Finland. But soon after, 'projects to develop power and transport facilities were accordingly considered especially appropriate for Bank financing' (Mason and Asher 1973: 150-1).

This change was specifically the result of developing country pressures, but also the consequence of the Bank's internal bureaucracy convictions. In more 
general terms, it translated the dominant beliefs on development among economists, political leaders and even business leaders at that time. It acknowledged the economic success of industrialization in the Soviet Union, it responded to the failure of the neoclassical ideas to cope with the great depression, it revealed the predominance of the Keynesian thought, it expressed the optimism about the future of capitalism and democracy after the victory over Nazism, it reflected the emergence of a managerial or technobureaucratic ideology all over the world as large corporations and governments assumed the leadership of the dynamic economies in the capitalist and in the communist camp. In the First and the Third World, it was confirmed by the GDP growth rates all over the world that, from the mid-1940s to the late 1960s, doubled in relation to the nineteenth and the first half of the twentieth century.

Under these pressures and conditions the Bank defined and increasingly broadened its development strategy, particularly in the 1960s. For sure, the Bank did not commit itself to a theory of development, nor defined a precise strategy. The Bank is a practical or pragmatic institution that avoids rhetoric and ideology as much as possible. Besides, it is a big institution. Its directors and its staff come from all parts of the world and represent a diversified and contradictory set of interests and ideologies. Thus the Bank never produced a document officially defining its views on development. Yet, the Bank is 'an intellectual actor' that creates, interacts, facilitates, absorbs, disseminates and applies ideas (Stern: 1992). Thus, it cannot avoid either theory or ideology. Always prudent, from the 1950s to the 1970s the Bank did not define a coherent strategy, responding to the dominant views of the time. But in many ways it actively participated in them. Rosenstein-Rodan once said that the Bank has usually been a follower and at times a rather reluctant follower. ${ }^{9}$ As a follower, the Bank essentially embraced the basic ideas of development economics. Besides requiring a favourable climate for domestic and foreign investment and sound macroeconomic policies the requisites that orthodox economics usually assume to be sufficient to promote growth - the Bank affirmed that it was necessary to finance strategic infrastructure projects led by state-owned corporations, to finance industrial and agricultural projects, education, population planning, and finally, with Robert McNamara, to directly flight poverty - and, accordingly, oriented its loans. Yet, in the late 1970s indications of a crisis were already noticeable, as the third world countries, whose development strategy had been up to that moment successful, now presented increasing problems. Simultaneously, distortions in project lending increased, projects were not completed as planned, and this became a matter of increasing concern in the Bank.

In the 1980s the original strategy of the Bank fell apart, as economic growth slowed down everywhere, as the welfare state in the North and national development in the South were challenged; as the Keynesian consensus broke 
down; as development economics collapsed, as neo-classical economics recovered forces with monetarism, rational expectations and the rational choice school; as the conservative, neoliberal wave took minds and won governments in the UK and the United States; as the market triumphed and all economic evils were attributed to the state.

The downfall of communism and the 1989 democratic revolution in Eastern Europe were only the final ad - or the inevitable consequence - of a statist model of growth whose lifespan was limited by definition and which has ay last, exhausted its virtualities. Such a model was never fully adopted by development economics or by the Bank, but its failure appeared, at least initially, as the confirmation of the much more moderate original development strategy of the Bank.

\section{The New Right and the Crisis of Development Economics}

The slowdown of the world economy and the acceleration of inflation rates in the 1970s gave rise to stagflation. The Keynesian consensus broke down and an opportunity emerged for the rise of a New Right intellectually well equipped for fighting the state.

The successful attack on the state led by the New Right came at the right moment, following rapid expansion of the state. Today criticism of the state is widespread. It is possible to detect neoliberal arguments and rhetoric everywhere, but particularly in the United States, as the politically and ideologically dominant nation in the world. The welfare state was the object of severe critique. Everywhere the state was put on the defensive. Privatization, trade liberalization and deregulation are on the agenda of practically all governments.

The New Right criticized the state successfully, but it was not able to provide a real alternative. Import protection was not a real constitutive element of the welfare, social-democratic state, but just an industrializing strategy for the takeoff. Long before the Bank was captured by the neoliberal wave it had criticized import substitution and promoted trade liberalization. ${ }^{10}$ Referring to neoliberalism, Claus Offe observes that it is significant that "its failure to demonstrate that "advanced capitalism-minus-the-welfare-state" would actually be a workable model' (1980: 152-3).

The fact that neo-liberalism is a rhetoric rather than a practice does not mean that the conservative wave was not significant. It was, particularly in the political, ideological and intellectual arenas. It just suggests that the rhetoric 
lacked realism, that its precepts were too much in conflict to the real needs of society to be applied.

In economic theory the main target of the New Right was, besides Keynes, development economics, that, since the mid-1970s had been in crisis. This crisis was once dramatically noticed by one of its pioneers, Arthur Lewis, who said in 1982: 'Development economics is dead'. ${ }^{11}$ Less dramatically Albert Hirschman wrote a paper on the subject: 'the rise and decline of development economics', where he says that 'the forward movement of our sub discipline has notably slowed down ... new ideas are ever harder to come by and the field is not adequately reproducing itself' (1981: 1).

If development economics was in crisis, the Bank's development strategy was also in crisis. Since the 1950s the Bank had been an institution of development economists. Actually, the Bank houses the largest group of development economists in the world. Although the Bank, as a huge bureaucratic institution, was never fully subordinated to any economic theory, including development economics, its decline was very much a problem to the Bank and its staff.

Hirschman presents two possible explanations for this decline: one is that the problems development economics was addressing, in fact, disappeared, the other is the disappointing realization that the 'solutions' are not at hand. After discarding the two explanations, he attributes the crisis to 'the excessively heterogeneous ideological make-up of the new discipline and to the unreasonable hopes and ambitions that overloaded it. The first case is related to the alliance of neo-Marxism and orthodox monoeconomics'. Development economics criticized monoeconomics, affirming that the economic analysis used in the industrial countries must be changed to cope with the particular characteristics of underdeveloped countries, but adopted the idea that mutual benefits prevailed over conflicting ones in the relationship between industrial and underdeveloped countries. Yet, neo-Marxist attachment to development economics divided the camp, as it provoked doubts about the basic harmony of interests between the North and the South. On the other hand, 'the neo-classical or monoeconomists were sharpening their own knives for an assault on development policies'. They 'concentrate on a single, simple, but to them capital, flaw of these policies: misallocation of resources' (1981: 18). And development economists were not able to adequately answer these critiques, (1) because development proceeded at very different rates in the various countries, so that the concept of a unified body of analysis and policy recommendations became victim of its very success; (2) because 'a series of political disasters struck a number of Third World countries from the sixties on, disasters that were clearly somehow connected with the stress and strains accompanying development and "modernization" (1981: 20); and 
because, I would add, distortions in the allocation of resources indeed increased with state intervention.

The first of these explanations deserves special emphasis. The crisis of development economics was caused, in large part, because it was successful, not because it failed. The industrial revolution, the take off, that was the major concern of development economics, indeed took place in many Latin American and Asian countries. In the 1940s or in the 1950s they were agricultural, precapitalist, or capitalist-mercantilist types of economies. Savings were very low. A local bourgeoisie and a technobureaucratic bourgeoisie hardly existed. Forty years later the situation had changed dramatically. Underdevelopment had not been overcome, but its main characteristics and problems had changed. As Fishlow observes, 'assumptions that were appropriate in the mid-1950s were rendered invalid in part by the very transformation development economists sought to induce' (1991: 1730), the rate of savings increased, markets were developed, income was concentrated. then the major problems the semiindustrialized or 'industrialized underdeveloped' countries' ${ }^{12}$ faced were no longer low savings, insufficient protection for the local and infant industry, absence of institutionalized markets, lack of entrepreneurs, but excessive foreign indebtedness, increasing balance of payment problems, fiscal indiscipline, high inflation rates, protectionism, distorted prices, excessive state intervention - ail leading to poor allocation of resources and a fiscal crisis of the state and also concentration of income in the hands of a new middle class and a small class of very wealthy individuals while the mass of the population remained immersed in poverty. The emphasis of the development strategy could no longer be based on import substitution, forced savings, state intervention, but on export-led development, on the reduction of the state, on macroeconomic discipline, on education, on technological development promotion as part of a new and targeted industrial policy, on environment protection.

The changes produced in the underdeveloped economies by the industrializing economic policies were so profound, that they made the very analysis that originated these policies invalid or outdated. Thus, the crisis of development economics should not have taken its adherents and the Bank as much by surprise as it did. Development economists should not be so dismayed or so attached to dated ideas - when new economic facts undermine their models and strategies, particularly if one remembers that, criticizing orthodox economists, they usually adopted a historical and structuralist approach. That is, in contrast to neoclassical economists, they learned to view economic systems as historically situated, ever changing phenomena, requiring permanent adaptation of the theories that attempt to analyse them and constant redefinition of the proposed economic strategies. Development economists should be aware of this fact, but there is a big distance between being aware and acting accordingly. The 
simple recognition of new historical facts requiring the rejection of old theories and strategies is always a very difficult, a very painful task.

\section{The Rise of a New Orthodoxy}

A much easier task was faced by orthodox economists. They never adopted a historical approach. And they always affirmed monoeconomics. Thus, when development economics faced a crisis, they proclaimed that development economics had always been wrong - that finally the truth of orthodoxy prevailed. They had in their favour two basic facts: (1) the increasing distortions in state intervention provoked by aggressive interest groups and incompetent governments that were not following development economics' prescriptions, but were just acting according to populist or developmentalist standards; and (2) the diminishing differences between the underdeveloped economies and the industrialized ones, as the developing countries industrialized and adopted modern capitalist institutions.

The attack against development economics began at its weakest point: import substitution, Development economists were quite aware of the shortcomings of this strategy, of its limited lifespan. They knew very well that its only argument the infant industry argument - would be valid just for a short period of time. But one thing is what development economists believe and say, another, what selfdeclared followers believe and do. In Latin America development economics was coopted by populism and national developmentalism. Then, it was not surprising that Celso Furtado, Planning Minister of Brazil in 1963 and one of the pioneers of development economics, was severely criticized for the 'orthodox character' of the policies included in his Plano Trienal. I had the same experience as Finance Minister in 1987, accused of being 'conservative' and 'IMF's friend' for my commitment to fiscal discipline.

Inside the Bank the works of Bela Balassa (Balassa et al. 1971), and outside, the contributions of Harry Johnson (1967), Little et al. (1970) and Max Corden (1971), had a devastating consequence on the views of the economic profession about the import substitution strategy. The effective rate of protection concept, that became popular in the 1970s, and the many studies on the subject, unmasked the excessive protection and highlighted the hidden price distortions. In the 1970s Jagdish Bhagwati (1978) and Anne Krueger (1978) - supported by the National Bureau of Economic Research (NBER) - published influential studies on trade liberalization experiences. Later Krueger would be chief economist at the Bank. In the 1980s an encompassing and persuasive study on 
trade liberalization experiences was conducted by three influential Bank economists, Papageorgiou, Michaely and Choksi (1991). ${ }^{13}$

As a matter of fact, the attack on the import substitution strategy and the adoption of trade liberalization as a basic reform to be undertaken in developing countries did not need to be related to the neo-liberal wave. Free trade is a longterm proposal of all good economists. Protectionism may be justified, but only in special historical conditions. One does not need to be a neo-liberal, or even a neoclassical economist, to oppose protectionism. Yet, trade liberalization was used as a neo-liberal banner all over, including in the Bank.

Anne Krueger should probably be particularly credited for this at the Bank, where her intellectual influence was decisive. Her ideological commitments are already very clear in her classical paper, 'The political economy of the rentseeking society' (1974). After her influential 1978 study on trade liberalization experiences, her influence on the policymaking Washington community increased significantly. When she became chief economist at the Bank, in the early 1980s, this influence was realized. She had a good argument - trade liberalization. To support it she adopted an ingenuous strategy of persuasion. She and several other economists identified trade liberalization with exportorientation and market-orientation, in this way coopting the extraordinary economic performance of the Asian tigers to the neo-liberal ideas ${ }^{14}$

This astute strategy - an excellent demonstration of the importance of rhetoric in economics - was cheerfully adopted by Asian economists. ${ }^{15}$ They are perfectly aware of the substantial degree of state intervention in their economies, but, since these economies are indeed export-oriented and highly competitive internally and in relation to other countries, they may be adequately called 'market-oriented'. By calling their economies market-oriented, and by falling to distinguish 'market-orientation' from 'market-coordination', the Asian policymakers deliberately underplay the strong role the state performs in their countries. And so they conformed with the dominant ideology in the West. As it is convenient to neoliberals to present the Asian tigers as a confirmation of their theories, it is convenient for the Asian tigers to accept this label: 'market orientation' 16

Already in 1987, in a symposium sponsored by the Bank, Jeffrey Sachs produced an able critique of the Bank's new strategy, emphasizing that 'the East Asian exemplars of outward orientation demonstrate the practical distinction between export promotion and liberalization, i.e., laissez-faire policies, a distinction which casts doubt on some of the policy advice emanating from the international institutions' (1987: 293). Yet, this critique did not prevent the Bank, and more generally Washington, from making this identification of the Asian 
export-led economies with neo-liberal ideals. The Bank had solid studies that fully demonstrated the advantages of an export-led strategy, when compared with the import substitution strategy. ${ }^{, 17}$ As the export-led strategy is, in principle, less interventionist than the import substitution strategy, export orientation was easily identified with full liberalization of the economy.

In this way the Bank, in the early 1980s, increasingly adopted a 'new orthodoxy' (Sachs 1987), that a few years later Williamson would call 'the Washington consensus' (1990). The new strategy, strongly influenced by the dogmatic neo-liberal approach, was based on a simple diagnosis. The crisis the Latin American and, more broadly, the highly indebted countries face has two basic causes: economic populism, leading to fiscal indiscipline, and the excessive growth of the state, related to protectionism. The debt crisis itself was minimized, and, since the Brady Plan (1989), assumed to be solved. ${ }^{18}$ The fiscal crisis, i.e. the basic insolvency of the state, was viewed as just an internal problem to be attacked by fiscal adjustment. Poor allocation of resources, according to the new orthodoxy, would be automatically solved by trade liberalization and privatization. According to French-Davis and Meller, structural adjustment in Latin America was 'conditioned or oriented to the service of foreign debt:

a biased outlook on Latin American countries seems to predominate in Structural Adjustment Loans. There is noticeable hostility towards the government and public enterprises since both, according to the World Bank's view, generally imply a hindrance to growth. Government involvement in the economic sphere inevitably introduces 'distortions'; for this reason, government's participation in the economy must be curbed sharply.... The evidence in Latin America on these issues indicates that they cannot be seen as black and white, but rather as much more complex matters. (French-Davis and Meller, 1990: 5)

Yet, given this diagnosis, the new role of the Bank was very clear: while the Fund would continue to address the short-term balance of payment and stabilization problems, the Bank would push for structural reforms, i.e. for trade liberalization, privatization and deregulation. This role was already clearly defined in the Baker Plan, 1985, that intended to solve the debt crisis with a basic formula: 'adjustment with growth and structural reforms'.

The mild critical tone involved in this description may suggest I oppose structural reforms. Actually I have no doubts on the need for the reduction of the state apparatus, for trade liberalization, privatization and deregulation. I am essentially in accord with the structural reforms the Bank promotes. As finance minister in Brazil, in 1987, I strongly pushed for these reforms. The technical support of the Bank was precious to me in that moment, particularly on the area 
of trade liberalization. But I never accepted the dogmatic and ideological character that these reforms increasingly assumed in the Bank - a dogmatic and ideological character that I was better able to perceive in the conversations with Bank officials than in reading speeches and documents. ${ }^{19}$

In fact, the dogmatic neo-liberal views are more evident in the rhetoric than in the practice of the Bank. The practice is necessarily more pragmatic. The rhetoric, particularly in private conversation, is much bolder, in accord with the dominant views in Washington. The problem is that, in certain cases, these ideological views may lead to the adoption of radical policies, that are inconsistent with structural reforms. Radical, shock policies, for instance, may be in certain circumstances the only alternative to stop high inflation or hyperinflation, but it is very difficult to present convincing arguments in favour of abrupt, drastic, privatization or trade liberalizations,

Trade liberalization is a must in Latin America, but has to be carried out carefully. ${ }^{20}$ Some dangers are still present today. For instance, trade liberalization coupled with an overvalued exchange rate may have disastrous effects on local industry. The high interest rates prevailing in most Latin American countries are attracting a new flow of capital to the region, which automatically triggers rate changes. Governments, however, hesitate in promoting the necessary devaluation of the local currency, fearing the resurgence of inflation. This is happening today in Argentina and Mexico, but the Bank did not propose the slowing down of the liberalization process while the exchange rate adjusts to the right level.

My personal experience with the Bank in relation to trade liberalization was quite positive. Just after I assumed the Finance Ministry, Armeane Choksi was appointed as director of the Brazil Department. Choksi, who later would become one of my best friends in Washington, is a forceful and warm bank official and a bright economist, who, together with Dimitri Papageorgiou, (who came with him to the Brazil Department), and with Michael Michaeli, was just finishing a large study on trade liberalization episodes. They were strongly committed to trade liberalization - a subject they were more acquainted with than I or my chief economist, Yoshiaki Nakano. Yet, in my team I counted on José Tavares de Araújo Jr, a specialist in the subject, who was already preparing the tariff reform - the essential precondition for trade liberalization. Thus, Choksi did not have to convince me and my team to go ahead with the trade reform. My personal experience does not suggest imposition of policies by the Bank, or the adoption of standard policies for countries with different economic and political conditions. But I am convinced that the prevailing rhetoric in the Bank favours solutions like that. 
It was clear to me that trade liberalization was an essential tool to improve resource allocation and increase the international competitiveness of Brazil, provided that it was achieved in a gradual and planned way. My team and the Bank's team worked closely together on the reform, that was not implemented in 1988 only because I decided to resign in December 1987. Still as minister, when Choksi - very prudent as Bank officials are supposed to be when dealing with developing countries - told me he was interested in organizing a private seminar in Brasilia on trade liberalization, I suggested that the seminar should be public and in São Paulo or in Rio, so that businessmen could participate. In 1988 the seminar was indeed realized with a large attendance.

At no moment did the Bank exercise undue pressure on this matter. It was clear to me that I could favour market-oriented reforms and fight for fiscal discipline while disapproving dogmatic neo-liberal ideas aiming at the minimum state. I believe that my friends in the Bank shared the same view. There is no conflict in supporting trade liberalization and privatization, while believing that a leaner but stronger state is supposed to complement the market in its role of coordinating the economy.

\section{The Bank as Part of the Debt Power System}

The ideological transformation within the Bank was only possible given, on the one hand, the conservative, neo-liberal wave that swept departments of economics of the American universities after the early 1970s and led development economics to crisis, and, on the other hand, the presence of a conservative president in the White House from 1981.

With the victory of Ronald Reagan in the 1980 presidential elections, the Bank came under increasing pressure from its major stockholder. ${ }^{21}$ First, as observes Karin Lissakers (1991: 16), an 'ideological purge' was achieved within the American government; the Bretton Woods institutions came second. Given its earlier commitments to development economics, the Bank - or rather its staff - was suspected of 'liberal', statist or even leftist views by the American government. The role of the Bank as a provider of financing for strategic infrastructure projects was challenged. The view that the Bank had lost its raison d'être, unless it changed its strategies, unless it financed private business enterprises rather than government, became dominant within the American government.

It is in this unfavourable climate that the debt crisis broke out in 1982. The role the developing countries expected from the Bank was a very positive one. Whereas the Fund was viewed as a tool of the commercial banks, or, more 
broadly, of the international financial community, the Bank was supposed to hold a basic allegiance to the highly indebted countries, since its commitment was supposed to be with development, not with balance of payment adjustment. Yet, the Bank did not correspond to the expectations of the developing countries. Soon, it became clear that the Bank and the Fund were the two basic instruments that creditor countries used to manage the debt crisis and protect their commercial banks. ${ }^{22}$

The pro-creditor approach to the debt crisis that the Bank adopted defines the second aspect of its identity crisis. This crisis was defined by a conflict of interests between the debtor and the creditor countries, i.e. between the developing and the developed nations. The conflicting aspects of the crisis clearly surmounted the common interests in this case. It is not a question of imperialism or not. The imperialist ideas to explain underdevelopment definitely lost ground in the 1970s, when the Latin American new dependency theory became dominant among the moderate left in Latin America and the liberals or social democrats in the First World. Only the traditional or communist left and radical nationalists remained faithful to imperialist interpretation of underdevelopment ${ }^{23}$. Yet, even for the ones that essentially believe in the 'mutual-benefit claim' (Hirschman, 1981), which was adopted by development economics, the conflict in the case of the debt crisis is clear: the creditor countries wanted the interests on the debt to be paid, the debtors, unable to pay them, needed to cancel part of the principal. The Bank, which was created on the assumption of the mutual benefits, but had as its main objective, to promote growth in the developing countries, was trapped in a deep contradiction. It tried its best to find solutions that were mutually beneficial -that to a certain extent did indeed exist but when, in the end, this alternative was not feasible, it sided with the creditors.

In fact, in the 1980s, the creditor governments informally organized a power system to manage the debt crisis (Fig. 1), that had, at the top, the Treasury and the Federal Reserve, and as consulting groups, the finance ministers of the G-7 and the chairmen (around 20) of the major commercial banks; and as executive agencies, the Fund and the Bank. The Fund was directly charged with the task of negotiating with the debtor governments, the Bank performing a complementary and intermediary role in the negotiations. Both institutions using conditionality as the way to achieve conformity.

Some believe that the Bank, in adopting this role, lost an opportunity to perform its genuine role as a development bank. According to this view, the Bank 'failed' in not adopting a more active role in the search for solutions for the debt crisis, in not advocating debt relief from the beginning. Feinberg, for instance, says that 'the Bank took a back seat to the IMF, not sufficiently 
anticipating that severe austerity would defund the investment projects that were the Bank's stocks in trade as well as play havoc with nations' development plans' (1986: 7). As a matter of fact, given the pressures the Bank was undergoing in the early 1980s, the debt crisis presented it with a golden opportunity to rebuild its shaken relations with the conservative governments of its major stockholders.

Figure 1: The Bank as part of the debt power system

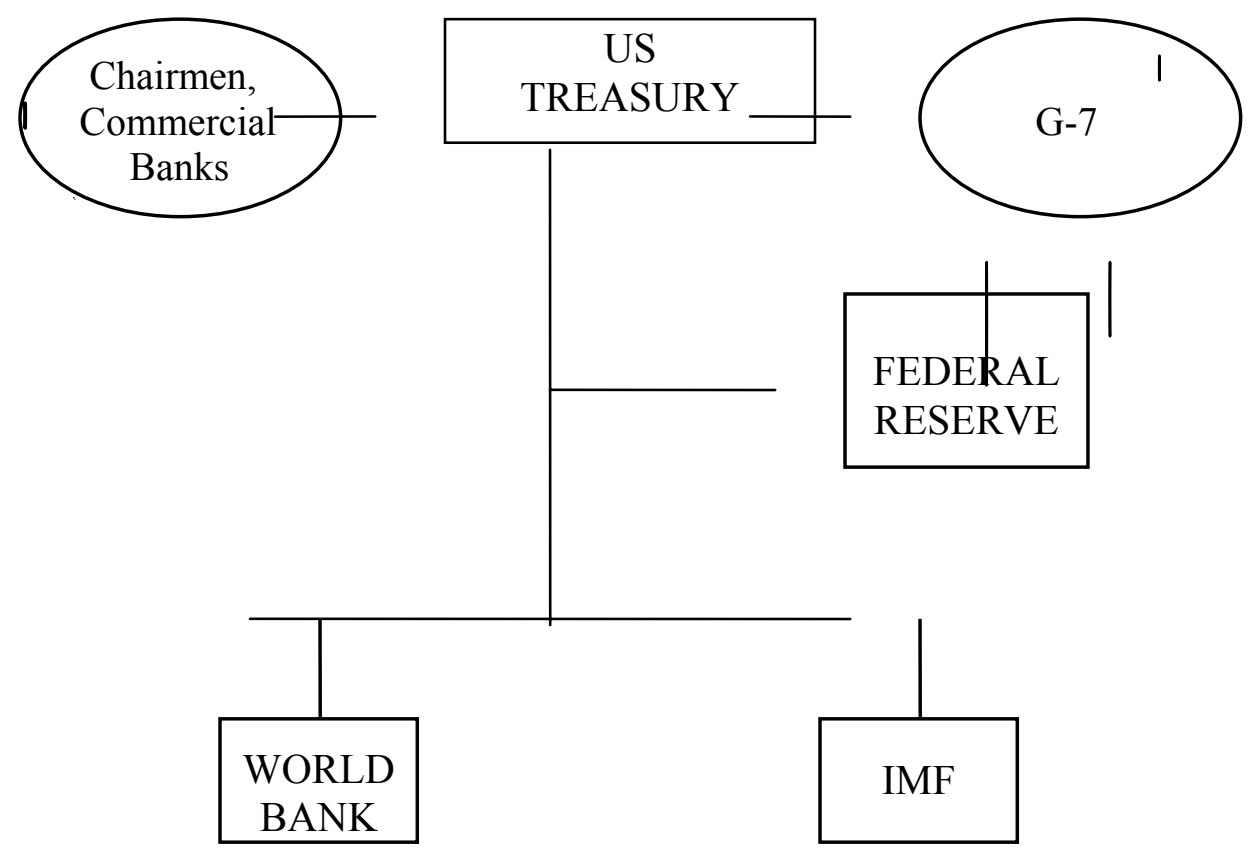

The debt crisis opened, de facto, the opportunity for the Bank to change from an institution that primarily finances and promotes development to an institution that imposes conditionality, that constrains developing countries to follow the economic directives the First World believes suitable. The priority for the creditor governments was to protect their banks, and, more broadly, the health of the international financial system. While the Fund remained responsible for fiscal and balance of payments adjustment, the Bank was made accountable for 'structure reforms'. And, in this way, the Bank - whose development economics based role as a provider of financial funds for strategic state investments was under attack - assumed a new role that the governments of the creditor countries believed essential: to promote privatization, liberalization and financial reform. Feinberg observes that, in doing that, "the Bank is in danger of becoming like the IMF - pushing simplistic, standardized formulas that slight the particular history, culture, and politics of individual nations' (Feinberg 1986: 12). Indeed this happened. Although the original objectives of structural adjustment loans were 
not to serve as tools to impose standard neo-liberal reforms on the developing countries, but 'to support - by means of series of (possibly three or four) discrete lending operations over a period of approximately five years - measures specifically designed to strengthen countries' balances of payments over the medium range' (Stern 1983: 92), this was the final outcome. The emphasis on macroeconomic stabilization turned into getting the prices right and reducing all forms of state intervention. Privatization, which was not in the original objective of structural adjustment loans, received an overwhelming importance. ${ }^{24}$ In the mix within the Bank's own staff a new dominance emerged of units and analysts focused on macroeconomic management, while the sector analysts and project design people were discriminated against. ${ }^{25}$ But, as a trade-off, the Bank, as a bureaucratic organization striving for survival and growth, recovered its prestige among Washington authorities, a prestige that was essential for the accomplishment of its basic organizational objectives. ${ }^{26}$

\section{The Financial Contradiction}

There is, however, a contradiction that is more serious than the lack of a definite development strategy and poor behaviour in the debt crisis. It is a contradiction that derives directly from its concept as a development bank. As a development bank, it is committed to LDC economic and social growth. This role is fully performed when the Bank loans the substantial IDA (International Development Association) funds. But, except for that, it does not count on free money. Thus, it is constrained to charge regular interest rates and fees for its services - the same rates and fees that commercial banks charge. If this is so, the logic it is pushed to follow is the logic of private banks: the logic of profits, the standard financial rule that, in the medium term, disbursements should be smaller than amortization plus interests and fees. Yet, as it is a non-profit organization, the clients -and sometimes its own officials - refuse to see the Bank as such, and so, they resist following the golden rule of the good debtor: only to borrow when return on investment is clearly higher than borrowing costs, On the other hand, at the moment the Bank ceases to provide a positive cash flow to the developing countries, only two alternatives are left. Either the country had already become developed before the Bank's net transfers turned negative to it - that was the case of the Western European countries after World War II - or the Bank ceases to perform the role of a strict development bank. This is essentially what is happening in relation to the developing countries.

There is an inner contradiction in the very idea of a development bank. The development banks' conception, starting with the World Bank, was based on an analogy with investment banks. Since the brothers Pereira created the first 
investment bank in France, in the last century, the underlying idea has been very simple. The bank will provide long-term financing for a given project - usually an industrial project. For some time the investment bank will have a negative cash flow with the business firm that presented the project. But, as soon as the project becomes operational, the respective returns will be sufficient to pay the loan. It will be the investment bank's turn to have a positive cash flow in relation to the firm, being reimbursed from principal plus interests.

The development bank should, in principle, ad as an investment bank. The only alleged difference is that, besides the project and the firm (a state-owned corporation) there is a developing nation-state. In the same way that the firm's cash flow should turn negative in relation to the investment bank once the project is completed, the country's cash flow should also turn negative once development is completed.

Yet, this simple reasoning is essentially mistaken. It is one thing to have concluded development projects, but another is to achieve development. A development project may be completed and provide a flow of funds that will repay the loan, but this does not mean that the country, that remained underdeveloped, achieved the financial capacity to accumulate export surpluses and pay the debt. If the developing country is not yet developed, this means that its per capita stock of capital is insufficient, that, besides more education and technology, it needs more capital. If, at this moment - before effective graduation of the borrower - the development bank reaches the point it is supposed to get back its money, it is a signal that it has also ceased to be able to perform the genuine role of a development bank. It is not anymore a net provider of funds. If the cash flow turns neutral or zero to the country, the development bank will look like a commercial bank that rolls-over debts. If it turns negative, the development bank will be actually an obstacle to the development of that country.

The World Bank is reaching the first stage - the stage of neutral cash flow towards the developing countries. Table 1 is clear on the subject. Even including IDA disbursements the Bank's cash flow is lending to zero. For Latin America it is strongly negative. Excluding IDA, the World Bank's total net transfers, that have been always positive, turn negative in 1987 and remain as such in the next years, as Table 2 shows. Thus, as a matter of fact, it is ceasing to be a development bank and changing into a kind of commercial bank.

The point or the stage a bank is supposed to stop having a negative cash flow in relation to its borrowers depends on two variables: the bank's capital and the borrowers' capacity to borrow. Both are limited. 
Table 1 Net transfers from the World Bank by region

(millions of US dollars; fiscal years)

\begin{tabular}{|l|r|r|}
\hline Region & 1992 & $1988-92$ \\
\hline Africa & 783 & 5,017 \\
\hline East Asia and Pacific & -264 & $-2,452$ \\
\hline South Asia & 1,429 & 8,406 \\
\hline Europe and Central Asia & -430 & $-6,469$ \\
\hline Latin America and the Caribbean & $-3,317$ & $-6,003$ \\
\hline Middle East and North Africa & -138 & $-1,098$ \\
\hline
\end{tabular}

Note:Disbursements from IDA Special Fund are included.

Source: The World Bank Annual Report 1992.

Table 2 Total net transfers from the World Bank (Nominal terms, millions of US dollars)

\begin{tabular}{|c|r|}
\hline Year & IBRD \\
\hline 1980 & 1,638 \\
\hline 1981 & 2,358 \\
\hline 1982 & 2,636 \\
\hline 1983 & 2,967 \\
\hline 1984 & 1,854 \\
\hline 1985 & 1,712 \\
\hline 1986 & 387 \\
\hline 1987 & $-1,494$ \\
\hline 1988 & $-4,099$ \\
\hline 1989 & $-3,562$ \\
\hline 1990 & $-2,063$ \\
\hline
\end{tabular}

Source: World Debt Tables, 1986, 1991.

The bank cannot for ever increase its capital. The borrowing capacity of a country is limited by its future capacity to pay. As the Bank's global cash flow is lending to zero in recent years, it is clear that both limits are being reached. There are no prospects for new substantial capital increases for the Bank, and most developing countries are today highly indebted countries. ${ }^{27}$

Development economics and the Bank's founders did not pay enough attention to the fact that capital flows in the form of loans will necessarily reverse sooner or later. As Cheryl Payer observes, 'everyone who uses a credit card knows that you cannot spend more than you earn for a prolonged period of lime without getting into trouble. And yet the conventional wisdom of development economics has been that this is exactly what Third World nations should do, because they are poor' (1991: 3). Certainly development economics and the Bank worried about the problem. Over a period, several exercises were done on the 
subject. But a basic - although poorly founded - optimism prevailed. Developing countries' pressures, the profit motive for the commercial banks, the bureaucratic-expansion motive within the World Bank were behind this optimism.

Yet, as a matter of the fact the Bank today is unable to provide an overall net inflow of capital to developing countries. It can have a negative cash flow with some countries or some regions, but at the expenses of a positive cash flow with others.

\section{The Bank's Response}

Throughout the 1980s the two basic contradictions that we have been examining deepened. The Bank does not have a positive development strategy anymore, i.e. a strategy that involves projects and requires external financing, justifying the existence of a development bank, nor does it dispose of the financial means that permit a negative cash flow towards the developing countries. On the other hand, for highly indebted underdeveloped countries it does not make sense to increase their debt. Rather they should reduce it.

The Bank was forced to give up its former development strategy, the big push idea, not only for theoretical (the crisis of development economics), ideological (the neoliberal wave) and political (the Reagan Administration) reasons, but also because of the poor performance of many project loans. The Bank was forced to reduce its net provision of funds to the developing countries given its own financial limitations plus the limitations of the recipient countries, Both crises represented a challenge to the institution. Which response did it give to them?

I have already suggested the response to the political pressure it suffered from the Reagan Administration: to accept a managing role in debt crisis management. Yet, the most general answers to the identity crisis I have been analyzing were: (1) the adoption of the market oriented structural reforms; and (2) the introduction of the adjustment loans and the sector adjustment loans. More recently, after the downfall of communism, a third answer was defined: to help Eastern Europe and the ex-Soviet Union in the transition to capitalism.

The market-oriented structural reforms came in good lime. They responded to a real need in the developing countries, as the previous developmentalist, projectionist and state based strategy had exhausted its potentialities. Eventually they were confounded with neo-liberalism, sometimes unduly when they just represented sensible economic policy, other limes, appropriately, when they were 
radical, ignored the particularities of the country, and weakened rather than strengthened the state.

As neo-liberalism aims at the minimum slate, it ignores a simple fact. Markets are institutions, not natural phenomena. In order to simply exist and also to avoid the monopolistic powers that are their own negation, markets depend on a strong rather than a weak stale. This stale can be, itself, an origin of monopoly power, an obstacle to the successful functioning of markets, but when this is true we are probably facing a weak and dysfunctional stale, not a strong and lean slate that the successful functioning of markets requires.

Yet, it is not the way that neo-liberal views prevailing in the Bank support market-oriented reforms that represents an obstacle to the definition of development strategy, but the fact that neo-liberalism pushes the Bank to limit itself to this 'negative' role. In most cases it is necessary to liberalize, to privatize, to deregulate, but these are 'negative' policies. They call for the withdrawal of the state, which, according to the moderate neo-liberal views should limit itself to investments in education and social policy, whereas radical neo-liberalism also proposes the privatization of education, health and environment protection. In this context, industrial policy, agricultural policy, trade policy and infrastructure investments are forgotten or underplayed. They would not be market-oriented. If the Bank accepts this view, why do we need a development bank?

The second response to its inner contradictions was the introduction of the structural and sector adjustment loans conditioned on policy reforms. Many project loans were not working well. A sense of frustration in relation to them became widespread within the Bank in the 1980s. On the other hand, the crisis of state-led development strategy had left enormous imbalances in the developing countries, urgently requiring balance of payment financing, debt reduction and fiscal discipline besides trade reforms, financial reforms, administrative reforms. The IMF was traditionally responsible for balance of payment and fiscal short term adjustment. It had gone somewhat long-term with the structural adjustment facility - but always making loans on a strict conditionality basis. Why couldn't the Bank make the complementary move, offering long-term structural adjustment loans? In this way, it would help the developing countries in their balance of payment problems, it would partially replace the commercial banks in financing the highly indebted countries, and would push economic reforms. Besides, structural adjustment loans may more easily be made consistent with financial limits the Bank and the recipient countries have. They may be more aptly compared with working capital financing, permanently rolled over by commercial banks, while project financing was germane to investment banks. 
Thus, with the structural adjustment loans, the Bank was making a realistic move but it was also making a political move. The new loans represented the passage of the Bank to the reign of conditionality. ${ }^{28}$ It had always been a political bank. Lichtensztejn and Baer (1986: 206-15), for instance, show how project loans were determined by political considerations - how communist regimes in Eastern Europe and untruthful political leaders in Latin America were excluded from the Bank's financing. Conditionality, however, was confined to the Fund. With the structural adjustment loans the Bank was formally entitled to directly influence economic policy. As Miles Khaler remarked, 'structural adjustment lending by the World Bank also reflected the new orthodoxy and represented an even more dramatic departure for that institution than the new emphasis in Fund conditionality' (1990: 42).

Project-based loans were the object of numberless critiques, but the logic behind them was straightforward, the need for a bank to finance the projects was clear, and achieved satisfactory results, according to the Bank's own internal assessment. The outcomes of the structural adjustment loans were less clear, given, on one hand, their eventual subordination to orthodox neoliberal views, and, on the other, the intrinsic difficulties of imposing economic reforms on unwilling governments or on governments that were disposed to cooperate but lacked political and/or technical capacity. According to a Bank study on adjustment lending (1990a), countries that received structural adjustment loans presented only slightly higher rates of economic growth than countries that did not. Structural adjustment was generally accompanied by faster growth of GDP but by declining investment rate (World Bank 1990b: 3-4). Yet a more recent study (1992), shows more favourable outcomes. According to this study, 'adjustment lending is associated with a recovery in growth rates and with improved policies' (1992: 2). But the Bank report adds: 'the adjustment process generally takes years and there can be significant costs in the transition. Most countries in the intensive adjustment lending group started the adjustment process early in the decade, but enjoyed gains, on average, only in the second half of the 1980s' (1992: 3).

Thus the Bank's, as well as the Fund's, influence on developing countries should not be underestimated because of the failure of some programmes the two institutions supported. We have seen that the developing countries' shift towards market-oriented policies corresponded to a deep change in the world economy and politics - a crisis of the state indicating the reversion of its cyclical growth pattern. It also corresponded to an historical pattern of growth, which usually begins with import substitution and strong state intervention, but, sooner or later, will lend to trade liberalization and increased market coordination. Thus, the shift to market-oriented reforms in the $1980 \mathrm{~s}$ corresponded to a normal historical trend, particularly in Latin America that had been artificially postponing them 
during the 1970s. ${ }^{29}$ Yet it is impossible to understand this shift if we do not take into consideration the external influence, particularly the influence of the Fund and the Bank. Conditionality may not have worked in specific cases. As Barbara Stallings observes:

It may well be the case that many individual Bank and Fund programs have been a failure, either in letter or spirit, so that their influence appears small. But, if the question is why the general thrust of Third World economic policy was so different in the 1980s than in the 1970s, the international factors loom large (1991: 3).

Conditionality has been always the major concern of critics of the Bretton Woods institutions. According to them, it would be an intrusion into internal affairs of developing countries, that assumes the incapacity of the local authorities. Nevertheless, as Joan Nelson underlines, 'actual compliance is greatest where governments are already strongly committed to reform' (1989: 19). On the other hand, Nelson and Khaler distinguish the commitment from the capability local governments have available to undertake reforms. Governments without political capability, even those willing to introduce reforms, were not able to do so. As Khaler observes: 'a number of divided and paralysed governments could not be pushed into such (reform) programs despite clear external pressure; their internal political authority had eroded, and domestic resistance was calculated to be too great' $(1989: 147) .{ }^{30}$ When governments are divided and paralysed this usually means that the state itself is in deep crisis. If conditionality does not take this fact into consideration, if Bank officials do not expressly try to help the willing government to strengthen the state it manages and to overcome the political obstacles it faces, reforms will most likely fail. ${ }^{31}$

As a finance minister, I did not have a critical view of the Bank's conditionality for two reasons: because I shared essentially the same views on the needed reforms, and also because I was sure that Brazil would only adopt the reforms that my team and I believed necessary. Under this perspective, conditionality could help rather than hinder reforms, since I could 'use' conditionality to get acquiescence from the Congress, from governors and other ministers to the reforms we were convinced to be necessary. Yet, the moment conditionality represents imposition, its chances of success are very small. And the possibility that it is just wrong is great. The assumption that opposition comes always from populist and statist positions is dangerous if not properly evaluated.

As I wrote in a recent paper with Gesner de Oliveira (1993), conditionality should be related to net transfers from the Bank to the country concerned. We can have positive and negative transfers, and high and low conditionality. A country with low conditionality and negative transfers is, in principle, a 
graduated country. If the Bank is belting on the country's prospects, its lending will be large, transfers will be positive, conditionality may be high, and outcomes will be positive. This is the cooperative game. The countries receiving structural loans from the Bank that the reports on adjustment lending portray are probably in this situation. In contrast, when there is a climate of conflict between the Bank and the country, as has been the case of Brazil in most of the recent years, net transfers will be negative, conditionality will be high, and outcomes in terms of output and investment, poor for the developing country. A fourth alternative (low conditionality, positive transfers) would apply to countries that developed a supportive attitude for political reasons.

The third and more recent answer of the Bank to its identity crisis - to help the ex-communist countries in their transition to capitalism - is just now taking place. A danger clearly threatens this action: the danger of ignoring that if Latin America faced abnormal times in the 1980s, Eastern Europe is facing extremely abnormal times in the 1990s. ${ }^{32}$ In abnormal times you have to combine conventional and unconventional solutions, orthodoxy and heterodoxy. Orthodoxy failed to solve Latin American stabilization problems in the 1980s, because conventional monetary and fiscal policies are a condition but not a sufficient one to face a deep fiscal crisis of the state and hyperinflation. Stabilizations in Latin America had to be introduced in a radical way. Bolivia (1985), Mexico (1987) and Argentina (1991) are good examples. On the other hand, structural reforms have to proceed more slowly. The 'big bang' approach for privatization, trade liberalization, deregulation is very dangerous, as it weakens instead of strengthening a state that is already very weak, when the state is supposed to institutionalize the new markets that are supposed to control these economies. In abnormal times it is necessary to think in innovative ways. For a large bureaucracy such as the World Bank this is a difficult challenge.

\section{Conclusion}

Developing countries usually concentrate their criticism of the Fund and the Bank on the excessive severity, the standardized character and the subtle arrogance that are embodied in conditionality. I will not extend this article to this subject. The real question is to discover if structural adjustment loans coupled with unilateral conditionality constitute a meaningful strategy to solve the Bank's identity crisis. I believe not.

In order to try to solve its identity crisis, the Bank will have to start from a better assessment of this crisis. It will have to examine the neoliberal approach; it will have to acknowledge the resurgence of development economics that has 
taken place in recent years based on the recovery of the concept of externalities and the development of the learning-by-doing strategy; ${ }^{33}$ it will have to admit that the neo-liberal, conservative wave, is already fading out for lack of effective policy proposals; ${ }^{34}$ it will have to adopt a more pragmatic approach to economics and economic policy; it will have, finally, to review the debt crisis, which was not solved although it receded as a reason for concern in the creditor countries when an agreement based on the Brady Plan was apparently successful in Mexico. ${ }^{35}$

I believe that this is already taking place in the Bank. Before Bill Clinton was elected President of the United States, the World Development Report 1991 provided an excellent indication of this new trend. Despite some ideological bias still present, this report represents an extraordinary advancement for the Bank. The staff was able to summarize the state of the art of its high-level research, and the neo-liberal approach was almost absent, except in some general statements. In the 'Overview' the report is quite clear:

A consensus is gradually forming in favor of a 'market-friendly' approach to development. The Report describes the various elements of this strategy and its implementation in a wide variety of country contexts. It goes further. It stresses the complementary ways markets and governments can pull together. If markets can work well, and are allowed to, there can be a substantial gain. If markets fail, and governments intervene cautiously and judiciously, there is a further gain $(1991: 1)^{36}$

In the same year, in the Annual Meetings of the Board of Governors of the World Bank in Bangkok, the new President, Lewis T. Preston, announced that the Bank would undertake a comparative study of economic growth and public policy in East Asia. ${ }^{37}$ The role of the government of Japan in this decision was important. Their representatives had for some time been manifesting their discomfort with the neo-liberal stand the Bank was adopting. ${ }^{38}$

It is too soon, however, to speak of 'a new consensus' or 'a new strategy'. This will be only possible when the critique of the neo-liberal approach advances and becomes more explicit. Besides, some self-criticism on the part of the Bank would be welcomed. Self-criticism in relation to its behaviour in the debt crisis, which is far from being over or fully solved - self-criticism in relation to the lack of pragmatism, for the ideologism, that in some moments became dominant in the Bank.

An essential part of the new consensus will have to be the realization of the limited possibilities of unilateral conditionality. It is essential to be modest in this matter. External influence is very powerful in developing countries. But this 
influence is only effective if it has as counterpart competent and critical local governments, that are willing to reform and adjust, and states that have not lost their basic capacity to sustain the local currency and to regulate the proper functioning of markets. To obtain the compliance of incompetent, corrupt or authoritarian governments, that just capitulate, helps very little.

On the other hand, the Bank will have to acknowledge a double financial constraint: its own limited financial means and the limited capacity highly indebted countries have to increase their debt ratios. In other words, it will have to recognize that the times when it could provide substantial net resources to developing countries are over. Rather than a development bank proper, the Bank is turning into a public commercial bank and a service institution oriented to economic development. As such, modesty, a very limited use of conditionality, a strong cooperation with competent and cooperative governments will have to be the rule.

The Bank may find all its shareholders against the approach. The developing countries will refuse to admit that the time for a strongly positive cash flow is over. They will request more capital increases, more loans. The developed countries will try to limit capital increases, while pressuring for more active conditionality. Between these two opposing forces, the Bank will have to find its way - an autonomous way? This will be only possible if the Bank stops depending on new capital increases, and also if the elites and the governments in the developed countries understand that it is worthwhile having an international institution that does not necessarily represent its views, but the views of both developed and developing countries. The 1980s were a bad decade for the Bank - a decade where it had to comply with the demands of the creditor countries on the debt crisis and with the ideological influences of an essentially antidevelopment ideology: neo-liberalism. Yet, there are signs that the 1990s will be a more favourable decade for the Bank.

In the first part of this essay I told a story, in the second, I tried a more general analysis. The case study showed how the Bank can be trapped in a power system. The broader analysis tried to demonstrate how a large and necessarily political organization such as the Bank permanently faces an identity crisis, as the economic and political environment changes, as economic theories and ideologies rise and fall and as the internal dynamics of the Bank, its capital structure and its organization change over time. Twenty-five years age, when the first history of the Bank was written it was a very different organization from today. It will certainly be very different twenty-five years from now. If it continues to be a successful organization or not, however, will depend on how well it is able to face and solve its recurrent identity crises. 


\section{REFERENCES}

Agarwala, A. N. and Singh, S. P. (eds) (1958) The Economics of Underdevelopment. New York: Oxford University Press.

Arida, Pérsio (1991) "A História do Pensamento Econômico como Teoria e Retórica", in José Márcio Rego (ed.) Revisão da Crise: Metodologia e Retórica na História do Pensamento Econômico. São Paulo: Editora Bienal.

Balassa, Bela et al. (1971) The Structure of Protection in Developing Countries. Baltimore, MD: Johns Hopkins University Press.

Balassa, Bela (1981) The Newly Industrializing Countries in the World Economy. New York: Pergamon Press.

Bhagwati, Jagdish N. (1978) Anatomy and Consequences of Exchange Control Regimes. Cambridge, MA: Ballinger for the National Bureau of Economic Research.

Boyer, Robert (1986a) La Flexibilité du Travail en Europe. Paris: Editions La Decourverte.

Boyer, Robert (1986b) "Wage Labour Nexus, Technology and Long Run Dynamics: an Interpretation and Preliminary Tests for U.S.". Paper presented at the workshop "Technological and Social Factors in Long Term Fluctuations", Siena, December 1986. Published in Di Matteo, Goodwin and Vercelli, eds. (1989).

Boeke, J. H. (1953) Economics and Economic Policy in Dual Societies as Exemplified by Indonesia. New York: Institute of Pacific Relations.

Bradford Jr., Colin I. (1991) "New Theories on Old Issues: Perspectives on the Prospects for Restoring Economic Growth in Latin America in the Nineties", in L. Emmerij and E. Iglesias (eds) Restoring Financial Flows to Latin America. Paris and Washington, DC: Development Centre of the OECD and Interamerican Development Bank

Bresser-Pereira, Luiz Carlos (1984) "Six Interpretations on the Brazilian Social Formation", Latin American Perspectives 11(1). Winter. Originally published in Portuguese 1982.

Bresser-Pereira, Luiz Carlos (1988) "Economic Reforms and the Cycles of the State", World Development. September 1993. Paper presented to the symposium "Democratizing Economics", São Paulo, July 1988 and revised in 1992. The original version was published in Portuguese in Revista de Economia Politica, 9(3), July 1989.

Bresser-Pereira, Luiz Carlos (1989) "The Perverse Macroeconomics of Debt, Deficit and Inflation in Brazil". Paper presented to the symposium "The Present and the Future of the Pacific Basin Economy", Institute of Developing Economies, Tokyo, July 1989. Published in Fukuchi and Kagami. dds. 1990.

Bresser-Pereira, Luiz Carlos (1990) "A Pragmatic Approach to State Intervention”. Revista de la CEPAL, no. 41, August.

Bresser-Pereira, Luiz Carlos (1991) "Economic Crisis in Latin America: Washington Consensus or Fiscal Crisis Approach?". Chicago: University of Chicago, East South Systems Transformations Project, Department of Political Science, Working Paper no.6, Jan. Published in Pesquisa e Planejamento Econômico, 21(1). April 1991. Paper originally presented as Magna Class in the XVIII National Meeting of Economy of ANPEC, Brasília, 4 December 1990.

Bresser-Pereira, Luiz Carlos (1992) "The Vanishing Motivation to Solve the Debt Crisis", São Paulo: Getúlio Vargas Foundation, Escola de Administração de Empresas, Department of Economics, Working Paper no. 9.

Bresser-Pereira, Luiz Carlos (1993) "Economic Reforms and Economic Growth; Efficiency and Politics in Latin America", in Bresser-Pereira, Maravall and Przeworski (eds) Economic Reforms in New Democracies. Cambridge: Cambridge University Press.

Bresser-Pereira, Luiz Carlos (1994) Economic Crisis and the State in Brazil. Boulder, CO: Lynne Rienner Publishers. 
Bresser-Pereira, L. and Y. Nakano (1984) The Theory of Inertial Inflation. Boulder, CO: Lynne Rienner Publishers 1987 (first Brazilian edition 1984).

Bresser-Pereira, L. and Gesner de Oliveira (1993) "Conditionality and Net Transference Games Between World Bank and LDCs". Paper presented to Group of 24, United Nations, February 1993.

Buchanan, James M. (1975) The Limits of Liberty. Chicago: Chicago University Press.

Buchanan, James M. (1989) Essays on the Political Economy, Honolulu: University of Hawaii Press.

Cardoso, Fernando Henrique (1977) "The Consumption of the Dependency Theory in the United States". Latin American Research Review, 10(3) Fall.

Cardoso, F.H. and Faletto, E. (1969) Dependency and Development in Latin America. Berkeley: University of California Press 1979. First Spanish edition 1969.

Castro, A.B. and Souza, F.P. (1985) A Economia Brasileira em Marcha Forçada. Rio de Janeiro: Paz e Terra.

Corden, Max (1971) The Theory of Protection, Oxford: Clarendon Press.

Coriat, Benjamin (1986) Science, technique et capital. Paris: Editions du Seuil.

Dall'Acqua, Fernando (1991) "L'Ajustement Macro-Economique et Libéralisation des Echanges Agricoles: un Defi por l'Amérique Latine". In A. Chominot (ed.) L'Agriculteur, le Marché et L'État, Paris: Economica.

Di Matteo, M., Goodwin, R. and Vercelli, A. (eds) (1989) Technological and Social Facts in Long Term Fluctuations. Berlin: Springer Verlag (Proceedings of the Siena Workshop, December 1986).

Dunleavy, P. and O'Leary, B. (1987) Theories of the State. New York: Meredith Press.

Economist, The (1986) "The World Bank", Special Survey, 27 September 1986.

Economist, The (1991) "The IMF and the World Bank". Special Survey, 12 October 1991.

Ellis, H. and Wallich, H. (eds) (1961) Economic Development for Latin America. New York: St Martin Press.

Fanelli, J., Frenkel, R. and Rozenwurcel, G. (1990) "Growth and structural reform in Latin America. Where we stand", paper presented to the conference "The Market and the State in Economic Development in the 1990s". São Paulo, October 1990. Published in Alvaro Zini (ed.) (1992).

Fanelli, J., Frenkel, R. and Taylor, L. (1992) "The World Development Report 1991: a Critical Assessment", Buenos Aires: Documento CEDES no. 78. (Document prepared for the Group of 24 at the United Nations.)

Feinberg, Richard E. (1986) "An Open Letter to the World Bank's New President”, in Feinberg (ed.) (1986) Between Two Worlds: the World Bank's Next Decade, Washington, DC: Overseas Development Council.

Finance Ministry of Brazil (1987a) Macroeconomic Control Plan. Brasília: Ministério da Fazenda.

Finance Ministry of Brazil (1987b) A Proposal for Negotiating the Foreign Debt. Brasília: Ministério da Fazenda.

Fishlow, Albert (1991) "Review of Handbook of Development Economics", Journal of Economic Literature, 29(4) (December).

Flora, Peter (1988) "Introduction" to Growth to Limits, in P. Flora (ed.) (1988).

Flora, Peter, ed (1988) Growth to Limits. The Western European Welfare States since World War II. Vol. 1, Sweden, Norway, Finland, Denmark, Berlin: Walter de Gruyter.

French-Davis, R. and Meller, P. (1990) "Structural adjustment and World Bank conditionality: a Latin American perspective", Santiago de Chile: CIEPLAN, no. 137 (November).

Furtado, Celso (1961) Desenvolvimento e Subdesenvolvimento. Rio de Janeiro: Fundo de Cultura. 
Furtado, Celso (1987) "Underdevelopment: To Conform or Reform", in Gerald Meyer (ed.) Pioneers in Development, Second Series, New York: Oxford University Press for the World Bank.

Gattei, Giorgio (1989) "Every 25 Years? Strike Waves and Long Economic Cycles". Paper presented to the colloquium "The Long Waves in the Economic Conjuncture - the Present State of the International Debates", Brussels, 12-14 January 1989.

Gilpin, Robert (1987) The Political Economy of International Relations. Princeton: Princeton University Press.

Gonzalez, Manuel, et al. (1990) O Brasil e o Banco Mundial: Um Diagnóstico das Relações Económicas. Brasília: Instituto de Pesquisa Econômica Aplicada, IPEA.

Grossman, Gene M. (1990) "Promoting New Industrial Activities: a Survey of Recent Arguments and Evidence". OECD Economic Studies, 14 (Spring).

Group of Twenty-Four (1990) "The role of the Fund and the World Bank in the context of the debt strategy". Washington, DC: Report to the Ministers by the G-24 Deputies, August.

Hagen, Everet (1962) On the Theory of Social Change, Homewood, IL: Dorsey Press.

Hirschman, Albert O. (1958) The Strategy of Economic Development, New Haven, Ct: Yale University Press.

Hirschman, Albert O. (1979) "The Turn to Authoritarianism in Latin America", in David Collier (ed.) The New Authoritarianism in Latin America. Princeton, NJ: Princeton University Press.

Hirschman, Albert O. (1981) "The Rise and Decline of Development Economics", in Essays in Trespassing, Cambridge University Press. Paper originally presented in 1979.

Johnson, Harry G. (1967) Economic Policies toward the Less Developed Countries, Washington, DC: Brookings Institution.

Kaldor, Nicholas (1963) "Taxation for economic development", Journal of Modern African Studies, 1(1) (March).

Kaletsky, Anatole (1985) The Costs of Default, New York: Twenty Century Fund/Priority Press Publications.

Kenen, Peter (1983) "A bail out for the banks". New York Times, 6 March.

Khaler, Miles (1989) "International financial institutions and the politics of adjustment", in Joan Nelson (ed.) (1989).

Kenen, Peter (1990) "Orthodoxy and its alternatives: explaining approaches to stabilization and adjustment", in Joan Nelson (ed.) (1990).

Krueger, Anne (1974) "The political economy of the rent-seeking society", American Economic Review, 64(3) (June).

Krueger, Anne (1978) Liberalization Attempts and Consequences, Cambridge: MA: Ballinger for the National Bureau of Economic Research.

Kuznetz, Simon (1966) Modern Economic Growth, New Haven, Ct: Yale University Press.

Leibenstein, Harvey D. (1957) Economic Backwardness and Economic Growth, New York: John Wiley \& Sons.

Lewis, Arthur W. (1954) "Economic development with unlimited supply of labour", The Manchester School, May 1954. (Reproduced in Agarwala and Singh (eds) (1958).)

Lichtensztejn, S. and Baer, M. (1986) Fondo Monetario Internacional y Banco Mundial: Estrategias y Políticas del Poder Financiero, San José, Costa Rica: Editorial Nueva Sociedad.

Lipietz, Alain (1989) Choisir l'Audace, Paris: Editions La Découverte.

Lissakers, Karin (1991) Banks, Borrowers, and the Establishment, New York: Basic Books.

Little, Ian M. D. (1982) Economic Development, New York: Basic Books.

Little, I., Scitovsky, T. and Scott, M. (1970) Industry and Trade in Some Developing Countries, Oxford: Oxford University Press. 
McClelland, David C. (1961) The Achieving Society, Princeton, NJ: D. Van Nostrand.

McCloskey, Donald N. (1983) "the rhetoric of economics", Journal of Economic Literature, 21(2) (June).

Mandel, Ernest (1980) Long Waves of Capitalist Development. Cambridge: Cambridge University Press.

Mason, E. and Asher, R. (1973) The World Bank Since Bretton Woods. Washington, DC: Brookings Institution.

Mosley, Paul (1987) "Conditionality as bargaining process: structural-adjustment lending". Princeton, NJ: Princeton University, Essays in International Finance no. 168.

Mosley, Paul (1990) "Structural adjustment: a general overview 1989-90", paper presented to the conference on "New Directions on Trade Policy", at the University of Paris I (PantheonSorbonne), 18-20 January.

Nelson, Joan M. (1989) "the Politics of Long-Haul Economic Reform", in Joan M. Nelson (ed.) Fragile Coalitions: the Politics of Economic Adjustment. Washington, DC: Overseas Development Council.

Nelson, Joan M. (ed.) (1990) Economic Crisis and Policy Choice. Princeton: Princeton University Press.

Nurkse, Ragnar (1953) Problems of Capital Formation in Underdeveloped Countries. Oxford: Basil Blackwell.

O'Connor, James (1987) The Meaning of Crisis. Oxford: Basil Blackwell.

Offe, Claus (1980) "Some Contradictions of the Welfare State", paper presented in Perujia. Italy 1980. (Published in Claus Offe, Contradictions of The Welfare State, Cambridge, MA: MII Press.)

Overseas Economic Cooperation Fund (1991) “Issues Related to the World Bank's Approach to Structural Adjustment - Proposal from a Major Partner", Washington, DC: the Overseas Economic Cooperation Fund, OECF Occasional Paper no.1, (October).

Papageorgiou, D., Michaely, M. and Choksi, A. (eds) (1991) Liberalizing Foreign Trade (seven volumes). Cambridge, MA: Basil Blackwell.

Payer, Cheryl (1982) The World Bank: a Critical Analysis. New York: Monthly Review Press.

Payer, Cheryl (1991) Lent and Lost. London: Zed Books.

Perroux, François (1955) "Note sur la Notion de Pôle de Croissance". Economie Appliquée 8, Séries D (January).

Prado Jr., Caio (1956) História Econômica do Brasil. São Paulo, Brasiliense. First edition 1945.

Prebisch, Raul (1950) The Economic Development of Latin America and its Principal Problems. New York: United Nations, Department of Economic Affairs.

Przeworski, Adam (1985) "Marxism and Rational Choice". Politics and Society, 14.

Ranis, Gustav (1981) "Challenges and Opportunities Posed by Asia's Super Exporters: Implications for Manufactured Exports from Latin America", Quarterly Review of Economics and Business, Summer. (Reprinted in J. Dietz and J. Street, eds. (1987) Latin America's Economic Development, Boulder. CO: Lynne Rienner Publishers)

Rohatyn, Felix (1983) “A Plan for Stretching Out Global Debt”, Business Week, 28 February.

Rosenstein-Rodan, Paul N. (1943) "Problems of Industrialization in Eastern Europe and SouthEastern Europe". Economic Journal 53, June 1943. (Reproduced in Agarwala and Singh (eds) (1958).)

Rosenstein-Rodan, Paul N. (1961) "Notes on the Theory of the Big-Push", in Ellis and Wallich, eds. (1961).

Rostow, Walt W. (1960) The Stages of Economic Growth. Cambridge: Cambridge University Press. 
Sachs, Jeffrey (1987) "Trade and Exchange Rate Policies in Growth-oriented Adjustment Programs", in Corbo, V., Gedstein, M. and Khan, M. ,eds. Growth-Oriented Adjustment Programs. Washington, DC: International Monetary Fund and the World Bank.

Schumpeter, Joseph A. (1911) The Theory of Economic Development, Oxford: Oxford University Press 1961. First German edition 1911.

Singer, Hans (1950) "The Distribution of Gains between Investing and Borrowing Countries". American Economic Review, 40, (May).

Stern, Ernest (1983) "World Bank Financing of Structural Adjustment", in John Williamson, ed. (1983).

Stern, Nickolas (1992) "The World Bank as "Intellectual Acto". Preliminary version of a paper for the Brookings" World Bank History Project, presented in a seminar in Washington, at the Brookings Institution, April 1992.

Williamson, John, ed. (1983) IMF Conditionality. Washington, DC: Institute for International Economics.

Williamson, John, ed. (1990) Latin American Adjustment. Washington, DC: Institute of International Economics.

World Bank (1990a) Adjustment Lending: Policies for Sustainable Growth, No.2. Policy and Research Series, Washington, DC: World Bank.

World Bank (1990b) Report on Adjustment Lending II: Policies for the Recovery of Growth. Washington: World Bank, Report for Executive Directors" Meeting, 26 March,

World Bank (1991) World Bank Development Report 1991. Washington, DC: World Bank.

World Bank (1992) The Third Report on Adjustment Lending: Private and Public Resources for Growth. Washington: World Bank, Report for Executive Directors" Meeting, 24 March.

World Bank (1993) The East Asian Miracle: Economic Growth and Public Policy. New York: Oxford University Press.

Zini, Alvaro, ed. (1992) The Market and the State in Economic Development in the 1990s. Amsterdam: North Holland.

1 Or 'developing', or 'less developed', as euphemistic reasoning in the First Word prefers to say.

2 The existence of a 'Washington consensus' was pointed out by John Williamson (1990). For a critique see Fanelli et al. (1990) and Bresser-Pereira (1991 and 1993). This consensus was reaching a neoliberal climax in that moment. Since then, and particularly since President Bill Clinton's election, it has started to be smoothed down.

3 Lewis was very specific on this subject: 'The central problem in the theory of economic development is to understand the process by which a community which was previously saving and investing 4 or 5 percent of its national income or less, converts itself into an economy where voluntary saving is running at about 12 to 15 percent of national income or more' (Lewis 1954: 416).

4 Lewis, following the traces of Smith and Marx, understood very well that the initial stages of development meant concentration of income in the hands of capitalists. His model is explicitly a model of income concentration: 'The central fact of economic development is that the distribution of incomes is altered in favour of the saving class. Practically all saving is done by people who receive profits or rents. Workers' savings are very small' (1954: 417).

5 Nurkse (1953) had already spoken about forced savings ('collective thrift') through taxation. Kaldor wrote a classical paper on the subject (1963). Forced savings through 
inflation are referred by Rosenstein-Rodan (1943) and extensively analysed by Lewis (1954).

6 According to Albert Hirschman, the call for planning in Latin America did not came only from ECLA (Economic Commission for Latin America of the United Nations), but was "powerfully backed by loanable funds, from such unimpeachable "establishment" quarters as the World Bank' (1979: 84).

7 Little, for instance, observes: 'Many cost-benefit analyses of agricultural and rural investments have been undertaken in the $1970 \mathrm{~s}$, a few by private researchers and many more by the World Bank and other agencies' (1982:

131).

8 From the Articles of Agreement of the International Bank for Reconstruction and Development.

9 From an interview with Paul Rosenstein-Rodan, Oral History Project of Columbia University. Quoted in Mason and Asher (1973: 468).

10 A study containing a critique of import substitution strategy was supported by the Bank in the early 1970s (Balassa et al. 1971). This study followed a previous one sponsored by The Brookings Institution (Harry Johnson 1967).

11 This phrase was used in 1982 to his students in Princeton University. Sérgio Werlang, who heard it, was my source.

12 I used this expression 'industrialized underdevelopment' in the 1970s. It was in the title of one of my books: A Economia do Subdesenvolvimento Industrializado (São Paulo: Brasiliense 1977).

13 In 1987, one month after I had assumed the Finance Ministry of Brazil, Armeane Choksi was designated director for Brazil in the Bank; I was already working on a trade liberalization programme, with Yoshiaki Nakano and José Tavares de Araújo Jr. We would develop a close cooperation, besides becoming very good friends.

14 Krueger does not say that the Asian tigers follow a neoliberal policy, but insistently underlines that the export-led economies are inconsistent with state intervention. At no point does she acknowledge that state intervention is very strong in these countries.

15 On the decisive role of rhetoric in economics see McCloskey (1983) and Arida (1991). Since a 'positive economics' is not a realistic possibility, the basic validity criterion of a proposition is Khunian: it is its acceptance by the scientific community of economists. In this process, the role of rhetoric or of the art of persuasion becomes critical.

16 In a first moment, after having participated from a symposium in Tokyo where most economists were oriental, I concluded that their insistence in calling their economies 'market-oriented' was a form of dissimulation (see Bresser-Pereira 1990). Lately, when I made the conceptual distinction between market orientation and market coordination (Bresser-Pereira 1993), I concluded that they are rather politically smart. Indeed their economies are market oriented, but this just means that they are strongly competitive. In coordinative terms, they are mixed, the state complementing the market in the allocation of resources.

17 See, particularly, the World Bank sponsored study by Balassa (1981).

18 I discussed this problem, showing that the debt crisis was not effectively solved by the Brady Plan, in 'The vanishing motivation to solve the debt crisis' (1992). 
19 I have made a careful analysis of the World Development Reports since 1980. As is usual in this kind of literature, they adopt a bureaucratic style. I was not able to find any straightforward neoliberal message. Yet, the neoliberal influence is discernible. This trend is reversed in the World Development Report 1991: the 'Challenge of Development', that already reveals an auto-critique inside the Bank, which I will discuss later.

20 Fernando Dall'Acqua, one of my closest associates in the Finance Ministry and a firm supporter of trade liberalization, observed recently, in a paper on agricultural trade liberalization, that in the developed countries the respective transitional costs are compensated by governments with generous subsidies, while 'most developing countries are unable to afford the budgetary costs involved in preventing the economic and political ramifications of trade liberalization. In the midst of a deep fiscal crisis they simply cannot afford this kind of transition costs unless it is included explicitly as special component of the World Bank policy-based ending' (1991: 364).

21 Writing in this time, Cheryl Payer notes: 'The crisis relations with the U.S. government is overt: the accession of Ronald Reagan to the presidency meant that for the first time in its history, the support of the U.S. executive branch to continued expansion of the World Bank is in question' (1982: 44). Robert Gilpin is still more clear: 'Some conservatives in the developed countries have regarded the World Bank and the IMF [sic] as purveyors of socialism and dispensers of wealth to profligate countries living beyond their means. This was certainly the view of the Reagan Administration until it realized that it needed the IMF to save the American banking system, then threatened by the debt crisis' (1987: 313). Soon after the Reagan Administration realized that the World Bank, although less trustworthy, could perform a similar role.

22 The Economist, in a long survey of the Bank (27 September 1986: 4) comments: 'the 1980s have so far proved an unhappy chapter in the history of the World Bank. The Bank failed to anticipate the debt crisis that erupted in 1982. Four years on, it is still trying to work out its response'.

23 The 'new dependency theory', whose basic work is Cardoso and Faletto's book (1969), should be clearly distinguished from the 'old dependency theory' or 'imperialist theory' of development, based on Lenin. See Cardoso (1977) and Bresser-Pereira (1982).

24 The basic objectives of the structural adjustment loans, proposed by the Bank at its 1979 Annual Meeting, were to: 'support a program of specific policy changes and institutional reforms designed to reduce current account deficit to sustainable levels' (Stern 1983: 89). That was supposed to be done through a more efficient use of resources in key sectors. According to Ernest Stern, 'the measures mainly fall within four areas: (1) the restructuring of incentives, which covers pricing policies, tariff reforms, taxation, budget subsidies, and interest rate policy; (2) the revision of public investment priorities in light of the changed international price structure and resource availabilities; (3) improvement in budget and debt management; and [sic] strengthening of institutions, particularly public enterprises' (1983: 93).

25 The overwhelming importance given to macroeconomic adjustment may be illustrated by an anecdotal but significant story: in 1991 the vice-president for Latin America visited Brazil and invited a group of economists for dinner. For almost three 
hours the macroeconomic short-run problems of the Brazilian economy were discussed. At no time did the vice-president show an interest in long-term development problems. He was just interested in fiscal discipline and a tight monetary policy, whose absence or insufficiency he assumed to be the main causes of the high Brazilian inflation. This fact not only illustrates the dominance of the macroeconomic problems in the Bank, but also suggests what kind of macroeconomics is dominant. In the year before, the Collor Plan had just failed after a huge fiscal adjustment (a 4 per cent of GDP budget surplus was produced this year) and the attempt to impose a fully orthodox monetary policy on the economy. This policy failed, not for economic populism, but because the monetary supply is endogenous when inflation is inertial, as it is in the Brazilian case (see Bresser-Pereira 1994).

26 The Economist, in a second survey of the Bank and the Fund (12 October

1991: 4), remarked: 'Their [the Bank's and the Fund's] role in the world economy remains as central today as the Bretton Woods architects intended. This is partly because they have proved extremely adaptable - and partly too, no doubt, because international bureaucracies are even harder to shut down than they are to set up'.

27 The highly expected 1988 general capital increase doubled the capital of the Bank, but its effective lending capacity remains limited, as the real increase in lending in recent years demonstrates. It is true that slow growth also originated in the demand side: in the fact that the Bank's loans are not competitive enough.

28 Yet, this change should not be over-emphasized. Through the 1980s around

75 per cent of total lending remained dedicated to project loans.

29 See Gustav Ranis (1981). This reasoning led Paul Mosley (1990) to argue that the appropriateness of structural adjustment programmes depends on the stage of development of each country. Middle income countries have already reached the stage where the transition from inward-oriented to export-oriented strategies makes sense. But this is not true for countries at an earlier stage, as with most African countries.

30 In the same vein the Group of Twenty-Four Report (1990: 11) affirms: "Since the reality is that so-called "non-economic" considerations often have economic consequences, the Fund (and the Bank) would be jeopardizing the success of adjustment programs by ignoring them'.

31 Paul Mosley, analysing conditionality and structural lending, concludes that the two more successful cases between 1986 and 1980 were those of Jamaica and Turkey, and observes: 'Radical as they are, these programs can scarcely be claimed as successes for conditionality, inasmuch as both governments have insisted that they would have implemented them even without pressure from the World Bank and the Fund' (1987: 33).

32 A meaningful distinction between 'normal' and 'abnormal' times is not easy. Yet. I believe it is possible to offer a definition of abnormal times: they occur when an acute fiscal crisis dominates the economy, state credit disappears or is dramatically reduced, and the country faces hyperinflation or is very near to it. Most countries in Latin America in the 1980s and in Eastern Europe in the early 1990s were in this situation.

33 For a survey on this matter see Grossman (1990) and Bradford (1991).

34 The victory of President Clinton in the 1992 presidential elections in the United States is an important political sign in this direction. 
35 Actually the contribution of the debt agreement to the relatively good performance of the Mexican economy is probably small. Much more important was the fiscal adjustment, the stabilization achieved in December 1987 through a heterodox shock, the structural reforms, particularly trade liberalization, and the prospects of being admitted in the North American Free Trade Association. This confidence-building strategy, plus the high differential of Mexican and international interest rates brought large foreign investments to Mexico, promoting some internal growth in spite of the unsatisfactory debt negotiation and the subsistence - although attenuated - of a fiscal crisis (see Bresser-Pereira 1993).

36 Yet these changes did not convince three eminent Argentinean economists, who wrote a long critical assessment of The World Bank Development Report 1991, where they criticize the Bank for attributing the slow-down of the World economies between 1960-73 and 1973-87 to low total factor productivity increase (which derives mostly from education and technological improvement), relegating to a second place, capital accumulation. And they add: 'in Table 2.2 one can easily observe that while there was no important change in growth rate of capital after 1973 for the sample as a whole, the same is not true at a less aggregate level. There was a decline of 1.8 percentage points between the periods for Latin America, and 0.8 for South Asia. Consequently, the constant overall average capital stock growth rate depends on East Asia and Europe making the difference. But the higher income countries in the sample are located in these regions: would the results have been the same had they been dropped? Have external shocks (let us say the debt crisis) no role in explaining differences in rates of capital accumulation between regions?' (Fanelli et al. 1992: 4).

37 The first volume of this study was published in 1993: It is a non-signed report; World Bank: The East Asian Miracle.

38 In October 1991 circulated in the Bank, a document issued by a Japanese government organization, the Overseas Economic Cooperation Fund, 'Issues related to the World Bank's approach to structural adjustment - proposal from a major partner', where a strong and insistent argument was made about the limits of market mechanisms. For instance: 'It is impossible to achieve optimum allocation of resources solely through market principle regardless of the level of development. There are many areas which cannot be handled by market mechanism ("market failure"), and government intervention is necessary to cope with such situations' (p. 11). 